\title{
DEMOGRAPHIC AND HISTOPATHOLOGICAL CHARACTERISTICS OF COLORECTAL POLYPS: A DESCRIPTIVE STUDY BASED ON SAMPLES OBTAINED FROM SYMPTOMATIC PATIENTS DEMOGRAFSKE IN HISTOPATOLOŠKE ZNAČILNOSTI KOLOREKTALNIH POLIPOV: DESKRIPTIVNA RAZISKAVA NA OSNOVI VZORCEV, PRIDOBLJENIH OD SIMPTOMATSKIH PACIENTOV
}

\author{
Genta CEKODHIMA ${ }^{1}$, Altin CEKODHIMA ${ }^{2}$, Arben BEQIRI ${ }^{3}$, Mehdi ALIMEHMETII ${ }^{1}$, Gerhard SULO ${ }^{4 *}$ \\ 'University Hospital Center “Mother Teresa”, Department of Pathology, Rruga e Dibrës 372, Tirana, Albania \\ 'Endoscopic Clinic “La Vita”, Rruga 'Xhanfize Keko' 13, Tirana, Albania \\ 3University Hospital Center "Mother Teresa”, Department of Surgery, Rruga e Dibrës 372, Tirana, Albania \\ ${ }^{4}$ University of Bergen, Faculty of Medicine and Dentistry, Department of Global Public Health and Primary Care, \\ Kalfarveien 31, Bergen, 5018, Norway
}

\section{ABSTRACT \\ Keywords: colorectal polyp, epidemiology, colonoscopy examination, Albania}

\section{IZVLEČEK}

Ključne besede: kolorektalni polipi, epidemiologija, kolonoskopija, Albanija
Background. Colorectal polyps (CP) are common among individuals older than 50 years. Some polyp types can precede colorectal cancer (CRC). This study aimed at describing histopathological characteristics of colorectal polyps in relation to age and gender among symptomatic patients referred for a colonoscopy examination during 2011-2014 in Tirana, Albania.

Methods. Study population included 267 individuals aged $\geq 20$ years and diagnosed with $\geq 1$ polyp during a colonoscopy examination. A total of 346 polyps were identified, excised and measured, and underwent histopathological examination.

Results. Adenomas accounted for $79.8 \%$ of all polyps and tubular type was the most frequent one (74.4\%). The majority of polyps $(42.5 \%)$ were small $(<1 \mathrm{~cm}), 38.7 \%$ of a medium size $(1-2 \mathrm{~cm})$ and $18.8 \%$ large $(>2 \mathrm{~cm})$. Adenomas were larger than non-adenomatous polyps $(\mathrm{p}<0.01)$

There was no gender difference with regard to patient age $(p=0.22)$ or polyp size $(p=0.84)$ Adenomas were more frequent among men compared to women $(p=0.02)$. Age was strongly related to polyp characteristics. The proportion of adenomas increased significantly with age $(p<0.01)$. Within adenomas, the proportion of villous types - a precursor of colorectal cancer - increased remarkably with age $(p=0.01)$. Older age was positively associated with potentially malignant adenomas (defined as adenomas $>1 \mathrm{~cm}$ and showing high-grade dysplasia) $(\mathrm{p}<0.01)$.

Conclusion. Adenomas accounted for the majority of polyps. Their morphology, size and malignant potential were related to patient age.

Uvod. Kolorektalni polipi (CP) so pogost pojav pri posameznikih po 50 letu starosti. Nekatere vrste polipov se lahko razvijejo $v$ kolorektalnega raka (CRC). Ta raziskava skuša opisati histopatološke značilnosti kolorektalnih polipov $v$ povezavi s starostjo in spolom med simptomatskimi pacienti, ki so bili napoteni na kolonoskopsko preiskavo v obdobju od leta 2011 do 2014 v Tirani, Albanija.

Metode. Raziskava je vključevala 267 posameznikov, starih 20 ali več let, ki jim je bil med kolonoskopijo diagnosticiran najmanj en polip. Skupno je bilo identificiranih, odstranjenih, izmerjenih in podvrženih histopatološki preiskavi 346 polipov.

Rezultati. Adenomi so predstavljali $79,8 \%$ vseh polipov, med njimi pa je prevladoval tubulni tip (74,4\%). Večina polipov (42,5\%) je bilo majhnih $(<1 \mathrm{~cm}), 38,7 \%$ je bilo srednje velikosti $(1-2 \mathrm{~cm}), 18,8 \%$ pa je bilo velikih $(>2 \mathrm{~cm})$. Adenomi so bili večji kot ne-adenomatozni polipi $(p<0,01)$.

$Z$ vidika starosti pacientov $(p=0,22)$ oziroma velikosti polipa $(p=0,84)$ ni bilo bistvene razlike med spoloma. Adenomi so bili bolj pogosti pri moških kot pri ženskah $(p=0,02)$. Starost je močno povezana z značilnostmi polipa. Delež adenomov se je s starostjo bistveno povečal $(p<0,01)$. $V$ smislu adenomov se je delež viloznih tipov - prekurzorjev kolorektalnega raka - $s$ starostjo izjemno povečal $(p=0,01)$. Višja starost je potrjeno povezana s potencialno malignimi adenomi (opredeljeno kot adenomi $>1 \mathrm{~cm}$, ki izkazujejo visoko stopnjo displazije) $(p<0,01)$.

Zaključek. Adenomi predstavljajo večino polipov. Njihova morfologija, velikost in potencial rakavosti je povezan s starostjo pacienta. 


\section{BACKGROUND}

Colorectal cancer (CRC) poses a great burden on population health. It represents the 4th and 3rd most common type of cancer among men and women, respectively (1). The estimated lifetime risk of developing the disease is $5 \%$ (2). Its incidence is increasing in the majority of countries, including South-Eastern European countries (3). Such increase is influenced (among other things) by the adoption of a Western-type diet and lifestyle (4). Costs related to CRC care account for $12 \%$ of cancer costs, making it the 2nd most expensive cancer to treat. CRC represents the 2nd cause of cancer-related deaths among men aged from 40 to 79 and women older than 80 years (2).

Colorectal polyps are very common among middle-aged individuals, with a prevalence being as high as up to $30 \%$. The epithelial type (either adenomatous or hyperplastic) represents the most common form of colorectal polyps, followed by non-epithelial (inflammatory and juvenile) polyps (5). Some polyp types, especially adenomas, are considered to be precursors of CRC $(6,7)$. Despite the evidence on the beneficial role of screening in reducing the burden of CRC (8), in Albania no screening programs or prevention measures have been implemented due to limited financial and human resources. No studies have explored the burden of CRC and its precursors in general population either. Therefore, available information on CRC incidence and mortality in Albania is based on calculated extrapolations using the data from neighboring countries and not taking into account genetic, cultural, environmental, social and racial differences across the countries (9). In such conditions, a less expensive alternative is to analyze polyp characteristics among symptomatic individuals in order to identify the burden of precancerous types among them.

The aim of this study was to explore for the first time in Albania, the morphologic and histopathological characteristics of colorectal polyps, and describe their distribution with regard to age and gender, using samples from 267 consecutive patients referred to the gastroenterologist for a colonoscopy examination.

\section{SUBJECTS AND METHODS}

\subsection{Study Population}

During 2011-2014, 1100 the patients aged $\geq 20$ years were referred by a family doctor or gastroenterologist to undergo a colonoscopy examination in relation to their symptoms (hematochezia, melena, positive fecal occult blood, abdominal pain, constipation or chronic diarrhea). A total of 67 patients $(69.8 \%$ men) were excluded due to the presence of CRC and another 766 patients (48.9\% men) were excluded due to the negative findings (lack of popyls) during the examination. The study population comprised 267 individuals $(64.8 \%$ men) with at least one diagnosed and resected polyp. The patients with colorectal cancer were the oldest (mean age 62.7 years) and those with negative findings were the youngest (mean age 49.9 years).

\subsection{Endoscopy Procedure}

Colonoscopy examinations were performed by two doctors. Any time a polyp was identified, a polypectomy procedure followed. In case of suspected malignancy, a cold forceps biopsy was obtained. The procedure was performed with Narrow band Imaging (NBI, EVIS EXERA II CV-180 Olympus ${ }^{\mathrm{TM}}$ ), high definition endoscopes and without the use of chromo-endoscopy during the identification procedure. Opened biopsy forceps of $7 \mathrm{~mm}$ and opened polypectomy snare with known diameter were used for measuring the polyps before piecemeal resection. Cold forceps and cold snare have been the polypectomy methods of choice for smaller polyps, and hot snare has been the method of choice for larger polyps.

\subsection{Histopathological Examination}

All specimens were histologically examined by a pathologist and, when in doubt (26 cases), a second, experienced pathologist was called to help reaching a decision. First, we measured the height and diameter of each specimen. After that, we put them in formalin solution. Once fixed, the specimen was sectioned in such a way that the relationship of the stalk to the head of the polyp was clear. To avoid missing a small focus of carcinoma, the entire specimen was submitted for histologic evaluation. The sections were stained with hematoxylin eosin (HE). All slides were examined under a light microscope (4X, 10X and 40X dry objectives).

\subsection{Classification of Polyps}

The 2010 World Health Organization (WHO) criteria were applied to assess the grade of dysplasia and architecture of the polyps (10). Adenomatous polyps were divided into low-grade or high-grade dysplasia. Depending on the presence and volume of villous tissue, adenomatous polyps were further classified as tubular, tubulovillous or villous.

The presence of hypercellular stroma, large mucin-filled cysts, the lack of smooth muscle core and flattened epithelium were used as criteria to diagnose a juvenile polyp. Finally, the presence of various degrees of inflammatory infiltrate, ulceration, edema and granulation tissue were the criteria on the basis of which the diagnosis of an inflammatory polyp was made. 


\subsection{Statistical Analysis}

Continuous variables are presented as mean and standard deviation (SD), while categorical variables are presented as numbers and proportions. Independent sample t-tests were used for comparisons of continuous, normally distributed variables. Categorical variables were compared using the chi square test. Two-sided tests with a 0.05 significance level were used. All statistical analyses were performed using STATA 13 (Stata Corp LP, 4905 Lakeway Drive, College Station, Texas, USA).

\section{RESULTS}

A total of 267 patients, aged $\geq 20$ years, with at least one resected polyp during the colonoscopy examination, were included in the study. The minimum number of polyps per person was one (in 211 patients) and the maximum five (in 2 patients). This yielded a total of 346 polyps (the unit of analyses).

Adenomas accounted for $79.8 \%$ of all cases. The majority of polyps $(42.5 \%)$ were small $(<1 \mathrm{~cm}) ; 38.7 \%$ were of medium size $(1-2 \mathrm{~cm})$ and the rest $(18.8 \%)$ large $(>2 \mathrm{~cm})$ (Table 1).

Table 1. Characteristics of the study participants.

\begin{tabular}{lcccc}
\hline $\begin{array}{l}\text { Characteristics } \\
\text { of the study } \\
\text { population }\end{array}$ & $\begin{array}{c}\text { All } \\
\mathrm{n}=346\end{array}$ & $\begin{array}{c}\text { Men } \\
\mathrm{n}=229\end{array}$ & $\begin{array}{c}\text { Women } \\
\mathrm{n}=117\end{array}$ & $\begin{array}{c}\mathrm{P} \\
\text { value* }\end{array}$ \\
\hline $\begin{array}{l}\text { Age (years), } \\
\text { mean (SD) }\end{array}$ & $54.1(13.3)$ & $54.8(13.1)$ & $52.8(13.6)$ & 0.22 \\
$\begin{array}{l}\text { Polyp type, n (\%) } \\
\begin{array}{l}\text { Non- } \\
\text { adenomatous }\end{array}\end{array}$ & $70(20.2)$ & $38(16.6)$ & $32(27.1)$ & \\
$\begin{array}{l}\text { Adenomatous } \\
\text { Polyp size (cm), }\end{array}$ & $276(79.8)$ & $191(83.4)$ & $85(72.9)$ & \\
$\mathrm{n}(\%)$ & $147(42.5)$ & $95(41.5)$ & $52(44.4)$ & \\
$\quad<1$ & $134(38.7)$ & $91(39.7)$ & $43(36.8)$ & \\
$1-2$ & $65(18.8)$ & $43(18.8)$ & $22(18.8)$ & \\
$>2$ & & & & 0.84 \\
\hline
\end{tabular}

*Obtained from chi square tests (for categorical variables) or two-sample t-test (continuous variables) comparing men and women

Hyperplastic and tubular types accounted for the majority ( $71.4 \%$ and $74.4 \%$ ) of non-adenomatous and adenomatous polyps respectively (Table 2 ).
Table 2. Distribution of non-adenomatous and adenomatous polyps by gender.

\begin{tabular}{lcccc}
\hline Polyp types & Total & Men & Women & $\begin{array}{c}\text { P } \\
\text { value }\end{array}$ \\
\hline $\begin{array}{l}\text { Non- } \\
\text { adenomatous } \\
\text { polyps, n (\%) }\end{array}$ & 70 & 38 & 32 & 0.92 \\
$\quad$ Hyperplastic & $50(71.4)$ & $28(73.6)$ & $22(68.8)$ & \\
$\quad$ Inflamatory & $14(20.0)$ & $7(18.5)$ & $7(21.8)$ & \\
$\quad$ Juvenile & $6(8.6)$ & $3(7.9)$ & $3(9.4)$ & \\
$\begin{array}{lcccc}\text { Adenomatous } \\
\text { polyps, n (\%) }\end{array}$ & 276 & 191 & 85 & $<0.01$ \\
$\quad$ Tubular & $205(74.4)$ & $151(79.1)$ & $54(46.6)$ & \\
$\quad$ Tubulovillous & $59(21.3)$ & $31(13.5)$ & $28(23.7)$ & \\
$\quad$ Villous & $12(4.3)$ & $9(3.9)$ & $3(2.5)$ & \\
\hline
\end{tabular}

\subsection{Gender-specific Analyses}

There were no statistically significant gender difference with regard to age $(p=0.22)$ and polyp size $(p=0.84)$. Adenomatous polyps were more frequent among men compared to women $(\mathrm{p}=0.02)$ (Table 1$)$. When analyzed separately, we did not observe gender differences in the distribution of non-adenomatous polyps $(p=0.92)$, while adenomas were distributed differently between men and women $(p<0.01)$. The tubular type accounted for $79.1 \%$ of all adenomas among men and only for $46.6 \%$ of them among women (Table 2).

\subsection{Polyp Size}

Overall, non-adenomatous polyps were smaller than adenomas $(p<0.01)$. Small polyps $(<1 \mathrm{~cm})$ comprised the absolute majority $(82.8 \%)$ of non-adenomatous polyps, while the distribution of adenomas with regard to size was more proportional. Middle-sized polyps $(1-2 \mathrm{~cm})$ accounted for $44.5 \%$ of cases, followed by small $(32.3 \%)$ and large $(>2 \mathrm{~cm}$ ) ones $(23.2 \%)$ (Table 3 ).

Table 3. Distribution of polyps by size.

\begin{tabular}{lccc}
\hline Polyp types & \multicolumn{3}{c}{ Polyp Size } \\
\cline { 2 - 4 } & $<1 \mathrm{~cm}$ & $1-2 \mathrm{~cm}$ & $>2 \mathrm{~cm}$ \\
\hline $\begin{array}{l}\text { Non-adenomatous polyps, } \\
\mathrm{n}(\%)\end{array}$ & $58(82.8)$ & $11(15.7)$ & $1(1.5)$ \\
$\quad$ Hyperplastic & $47(94.0)$ & $3(6.0)$ & - \\
Inflamatory & $11(78.6)$ & $3(21.4)$ & - \\
Juvenile & - & $5(83.3)$ & $1(16.7)$ \\
Adenomatous polyps, $\mathrm{n}(\%)$ & $89(32.3)$ & $123(44.5)$ & $64(23.2)$ \\
$\quad$ & $82(40.0)$ & $99(43.3)$ & $24(11.7)$ \\
Tubular & $7(11.9)$ & $19(32.2)$ & $33(55.9)$ \\
$\quad$ Villoulovillous & - & $5(41.7)$ & $7(58.3)$ \\
\hline
\end{tabular}


We did not observe any gender differences with regard to size when analyses were conducted separately among non-adenomatous polyps $(p=0.52)$ and adenomas $(p=0.71)$ (Figure 1).

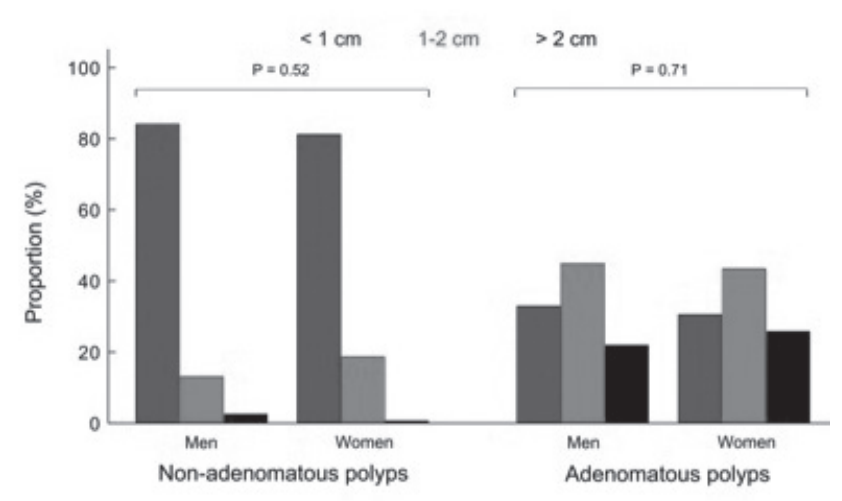

Figure 1. Gender differences pertaining to polyp size.

\subsection{Influence of Age on Polyp Characteristics}

A linear relationship was observed between patient age and type of polyp. Adenomas were more frequent than non-adenomatous polyps among all age groups, but this difference tended to increase with age $(p<0.01)$ (Figure 2$)$.

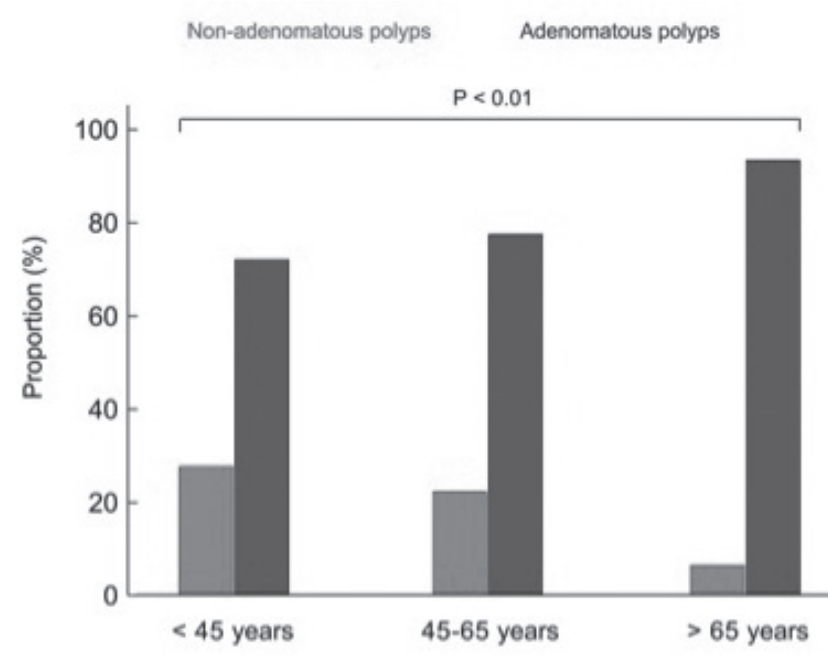

Figure 2. The distribution of polyps by age.

Age was also associated with subtype distribution among adenomas; tubular subtype accounted for $89.2 \%$ of all adenomas among patients $<45$ years, but this proportion dropped with increasing age to $74.8 \%$ among patients 45 65 years and further to $59.7 \%$ among those > 65 years. On the contrary, the proportion of villous subtype - the most important CRC precursor - increased from 1.5\% among patients < 45 years to $13.9 \%$ among those older than 65 years $(p=0.01)$ (Figure 3$)$.

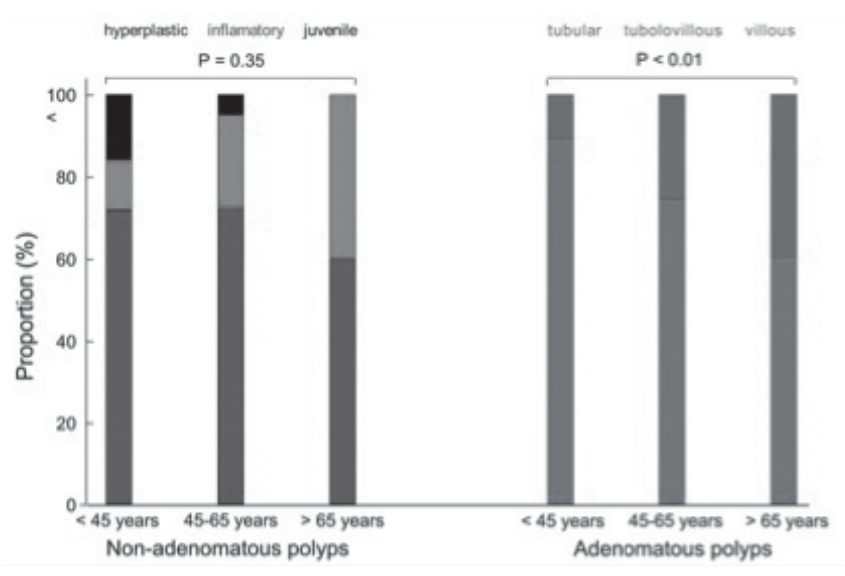

Figure 3. Age differences in the distribution of polyps.

Lastly, we explored the association between grade of dysplasia and patient age, and observed that older patients showed more often adenomas with high-grade dysplasia compared to their younger counterparts $(p=0.008)$. However, high-grade dysplasia was not uncommon among young and middle-aged patients, and accounted, respectively, for $29.2 \%$ and $43.2 \%$ of all adenomas in these groups (Table 4 ).

Table 4. Distribution of polyps by size.

\begin{tabular}{ccccc}
\hline & \multicolumn{3}{c}{ Age group } & \\
\cline { 2 - 4 } $\begin{array}{l}\text { Grade } \\
\text { of dysplasia }\end{array}$ & $<45$ years & $\begin{array}{c}45-65 \\
\text { years }\end{array}$ & $>65$ years & $\begin{array}{c}P \\
\text { value }\end{array}$ \\
\hline Low-grade dysplasia & $46(70.8)$ & $79(56.8)$ & $32(44.4)$ & \\
High-grade dysplasia & $19(29.2)$ & $60(43.2)$ & $40(55.6)$ & 0.008 \\
$<1 \mathrm{~cm}$ & - & $4(2.9)$ & - & \\
$\geq 1 \mathrm{~cm}$ & $19(29.2)$ & $56(40.3)$ & $40(55.6)$ \\
\hline
\end{tabular}

\section{DISCUSSION}

This study showed that adenomas accounted for $79.8 \%$ of all polyps and they were more frequent among elderly and male patients. Within adenomas, the proportion of villous type - a direct precursor of CRC - increased remarkably with age. Further, adenomas found in older patients had in $\sim 56 \%$ of cases high-grade dysplasia and were $>1 \mathrm{~cm}$ large (both indicators of a high malignant potential) (11). A direct comparison of our findings with previous studies is challenging due to differences with regard to study period and population (in terms of age, gender and ethnicity). In addition, it has been shown that the prevalence of adenomas based on autopsy studies is higher than that reported from studies based on endoscopy findings (12). 
A study conducted in Denmark during 1986-1987 reported that adenomas accounted for the majority (60\%) of the 305 examined polyps (13). A more recent analysis conducted in Western Australia reported that adenomas accounted for $70 \%$ of all polyps (14). In a study conducted in Canada in 2002, Khan et al. (15) reported that adenomas accounted for $83 \%$ of all polyps, followed by hyperplastic (12.3\%) and inflammatory (2.8\%) types. Among studies conducted outside Europe and North America, Tony et al. (16) reported that among 124 patients diagnosed with a polyp, $79.5 \%$ were adenomas, $10 \%$ juvenile, $9 \%$ hyperplastic and $1.5 \%$ inflammatory. The most recent published study (to our knowledge) was conducted in Iran in 2010 (17). Of the 856 polyps examined, $85 \%$ were adenomas. Of those, $56 \%$ were tubular, $17 \%$ villous and $27 \%$ tubulovillous. Findings from our study are in line with these previously conducted analyses.

\subsection{Public Health Implications}

To date, there is a general consensus on the beneficial role of screening average-risk individuals in their 50s every 10 years. Different suggested approaches (opportunistic or programmatic screening) help preventing CRC by removing polyps with high malignant potential (3) or detect CRC at an early stage, improving its prognosis. To illustrate, the 5 -year survival is $90 \%$ if CRC is diagnosed early (while still localized) and only $10 \%$ in advanced stages when distant metastases develop (18).

We showed that the proportion of patients with highgrade dysplasia and size $>1 \mathrm{~cm}$ accounted for $\sim 56 \%$ of patients older than 65 years. However, such adenomas with high malignant potential were not exclusively observed among older adults. They accounted for nearly $1 / 3$ of adenomas observed among younger (< 45 years) and $40.3 \%$ of those observed among middle-aged (4565 years) patients. Further, adenomas with a villous component (either tubulovillous or villous) accounted for $~ 10 \%$ of adenomas among patients < 45 years and $1 / 4$ of those among patients $45-65$ years. These results show clearly a potentially beneficial role of conducting screening programs among individuals in their fourth to fifth decade of life in order to identify polyps with high malignant potential and reduce the burden of CRC in Albanian population.

\subsection{Strengths and Limitations}

Our study is the first national study and one of the few recent analyses worldwide $(16,17)$ exploring histopathological characteristics of colorectal polyps and their distribution. However, it carries certain limitations, among which it is worth mentioning that the study population comprises consecutive symptomatic patients and not a representative national sample. Moreover, additional information on the disease stage would provide additional valid evidence. Further, we do not know the type and distribution of such polyps among the severe cases that died before undergoing colonoscopy examination.

\section{CONCLUSIONS}

This study provides evidence that precancerous lesions are very frequent among symptomatic patients undergoing a colonoscopy examination. Although such lesions are more frequent among elderly people, a relatively high proportion of adenomas with malignant potential were found among younger individuals. These findings support the need for prevention strategies and screening programs in order to reduce the risk of future CRC in the Albanian population.

\section{CONFLICTS OF INTEREST}

The authors declare that no conflicts of interest exist.

\section{FUNDING}

None.

\section{ETHICAL APPROVAL}

The information used in this study was collected at the examination clinic and variables allowing direct identification of participants removed prior to data analyses. The study was conducted in accordance with the code of Ethics of the World Medical Association (Declaration of Helsinki).

\section{REFERENCES}

1. Parkin DM, Bray F, Ferlay J, Pisani P. Global cancer statistics, 2002. CA Cancer J Clin 2005; 55: 74-108.

2. Gellad ZF, Provenzale D. Colorectal cancer: national and international perspective on the burden of disease and public health impact. Gastroenterol 2010; 138: 2177-90.

3. Center MM, Jemal A, Smith RA, Ward E. Worldwide variations in colorectal cancer. CA Cancer J Clin 2009; 59: 366-78.

4. Miller PE, Lesko SM, Muscat JE, Lazarus P, Hartman TJ. Dietary patterns and colorectal adenoma and cancer risk: a review of the epidemiological evidence. Nutr Cancer 2010; 62: 413-24.

5. Bond JH. Polyp guideline: diagnosis, treatment, and surveillance for patients with colorectal polyps. Practice Parameters Committee of the American College of Gastroenterology. Am J Gastroenterol 2000; 95: 3053-63.

6. Martinez ME, Baron JA, Lieberman DA, Schatzkin A, Lanza E, Winawer SJ. et al. A pooled analysis of advanced colorectal neoplasia diagnoses after colonoscopic polypectomy. Gastroenterol 2009; 136: 832-41. 
7. Cottet V, Jooste V, Fournel I, Bouvier AM, Faivre J, Bonithon-Kopp C. Long-term risk of colorectal cancer after adenoma removal: a population-based cohort study. Gut 2012; 61: 1180-6.

8. Wang FW, Hsu PI, Chuang HY, Tu MS, Mar GY, King TM. et al. Prevalence and risk factors of asymptomatic colorectal polyps in Taiwan. Gastroenterol Res Pract 2014: 985205.

9. Ferlay J, Steliarova-Foucher E, Lortet-Tieulent J, Rosso S, Coebergh $\mathrm{JW}$, Comber $\mathrm{H}$. et al. Cancer incidence and mortality patterns in Europe: estimates for 40 countries in 2012. Eur J Cancer 2013; 49: 1374-403.

10. Jass JR, Sobin LH. Histological typing of intestinal tumours. In: World Health Organization: International Histological Classification of Tumours. 2nd ed, 1993: 132.

11. Colucci PM, Yale SH, Rall CJ. Colorectal polyps. Clin Med Res 2003; 1: 261-2.

12. Giacosa A, Frascio F, Munizzi F. Epidemiology of colorectal polyps. Tech Coloproctol 2004; 8(Suppl 2): s243-7.

13. Johannsen LG, Momsen O, Jacobsen NO. Polyps of the large intestine in Aarhus, Denmark: an autopsy study. Scand J Gastroenterol 1989; 24: 799-806.

14. Patel K, Hoffman NE. The anatomical distribution of colorectal polyps at colonoscopy. J Clin Gastroenterol 2001; 33: 222-5.

15. Khan A, Shrier I, Gordon PH. The changed histologic paradigm of colorectal polyps. Surg Endosc 2002; 16: 436-40.

16. Tony J, Harish K, Ramachandran TM, Sunilkumar K, Thomas V. Profile of colonic polyps in a southern Indian population. Indian $J$ Gastroenterol 2007; 26: 127-9.

17. Hodadoostan MK, Reza F, Elham M, Mohammad Alizade AH, Molaie M, Mashaiekhy R. et al. Clinical and pathology characteristics of colorectal polyps in Iranian population. Asian Pac J Cancer Prev 2010; 11: 557-60.

18. Levin B, Lieberman DA, McFarland B, Smith RA, Brooks D, Andrews KS. et al. Screening and surveillance for the early detection of colorectal cancer and adenomatous polyps, 2008: a joint guideline from the American Cancer Society, the US Multi-Society Task Force on Colorectal Cancer, and the American College of Radiology. CA Cancer J Clin 2008; 58: 130-60. 